\title{
Impact of the Little Fire Ant, Wasmannia auropunctata, on Native Forest Ants in Gabon ${ }^{1}$
}

\author{
Kendra L. Walker ${ }^{2}$ \\ University of Michigan School of Natural Resources \& Environment, University of Michigan, Ann Arbor, Michigan 48109-1115, U.S.A.
}

\section{ABSTRACT}

The Neotropical little fire ant, Wasmannia auropunctata, is notorious for its negative impacts on the native biota of tropical islands, such as the Galapagos and New Caledonia, where it has been introduced. Here, I evaluate the impact of exotic W. auropunctata populations on continental Africa. I surveyed ants at nine sites in Lopé National Park in Gabon, Central Africa, and found a highly significant correlation between ant diversity and length of infestation by W. auropunctata. I found many more native ant species present in areas not infested with $W$. auropunctata $(39.0 \pm 4.6)$ compared with areas infested by $W$. auropunctata for approximately $5-10$ yr $(7.0 \pm 6.2$ and $1.7 \pm 1.2$, respectively). In infested areas, $W$. auropunctata made up the bulk of specimens collected in every plot. This study demonstrates that the threat posed by W. auropunctata to biodiversity is as serious in continental ecosystems as it is in the more fragile island ecosystems of previous studies. Introductions near waterways are particularly devastating: in Lopé, the infested territory is most extensive along waterways and occurs in a pattern that strongly suggests moving water facilitates colonization.

\section{RÉSUMÉ}

La petite fourmi rouge, Wasmannia auropunctata, est réputée pour ses impacts négatifs sur la biocénose indigène des îles tropicales où elle a été introduite, comme aux îles Galápagos et en Nouvelle-Calédonie. Cette étude évalue les conséquences des populations exotiques de W. auropunctata en Afrique continentale. En échantillonnant la myrmécofaune dans neuf sites au Parc National de la Lopé au Gabon, j’ai trouvé une forte corrélation entre la diversité de fourmis et la durée écoulée depuis l'arrivée de $W$. auropunctata. Les espèces de fourmi indigènes sont beaucoup plus nombreuses dans les zones encore vierges (39.0 \pm 4.6$)$ en comparant avec les sites envahis depuis environ 5 et 10 ans $(7.0 \pm 6.2$ et $1.7 \pm 1.2$, respectivement). Dans les sites envahis, W. auropunctata représentait la majorité des spécimens rencontrés dans chaque échantillonnage. Cette étude met en évidence la menace posée par W. auropunctata aux écosystèmes continentaux, tout comme l'ont montrées les études antérieures pour des écosystèmes insulaires plus fragiles. L'implantation près des cours d'eau est fulgurante: à la Lopé, l'essentiel du territoire envahi est situé le long des cours d'eau, suggérant un transport facilité par l'eau.

Key words: biodiversity; Congo basin; equatorial Africa; exotic ants; Gabon; invasive species; Wasmannia auropunctata.

THE CONGO BASIN RAIN FOREST REgION IS CRITICAL TO BIODIVERSITY CONSERVATION; it is the world's second largest and most intact tropical forest region and houses a remarkably diverse array of flora and fauna, particularly in terms of primates and large mammals (Besselink et al. 1998). While biodiversity conservation can often be difficult in developing tropical countries, such as those comprising the Congo basin, Gabon presents great potential for conservation due to the nation's low population density and newly established network of 13 national parks.

To realize this potential, assessment and control of factors that could diminish biodiversity in the region are essential. Research in the Congo Basin forests is often focused on high-profile, human-oriented activities such as logging and poaching. Although these activities are undoubtedly critical for conservation, other lesscontroversial issues, such as biological invasion, could rival these in ability to alter biodiversity, and thus deserve considerable attention as well.

Invasions by exotic species pose a serious threat to conservation of native flora and fauna because of their potential to reduce biodiversity and cause local extinctions. The little fire ant, Wasmannia auropunctata, is a well-known invader in the tropics. This tiny Neotropical ant is considered one of the world's worst invasive alien

\footnotetext{
${ }^{1}$ Received 23 January 2005; revision accepted 15 December 2005.

${ }^{2}$ Corresponding author; e-mail: klwalker@umich.edu
}

species (Lowe et al. 2000) because of its devastating effect on the native fauna. While previous studies have established the capacity of exotic W. auropunctata populations to drastically reduce the diversity of ants and other arthropods (Clark et al. 1982, Lubin 1984, Guilbert et al. 1994, Jourdan 1997, Le Breton et al. 2003), all of these studies have concerned island ecosystems. This study is the first to assess quantitative impacts on diversity in continental forests.

Most known introductions of W. auropunctata occur on islands, where the higher vulnerability of native species to exotic invaders has long been recognized (Atkinson 1989, Loope \& MuellerDombois 1989, Gillespie \& Roderick 2002, Le Breton et al. 2005). Continental tropical forests, however, are considered less susceptible to bio-invasions due to their high species richness (Rejmánek 1996). Invasion by W. auropunctata might therefore be predicted to be less devastating to the native fauna in these forests than in the insular habitats. Observations in Florida, where W. auropunctata was introduced around 1924 (Wheeler 1929) support this theory. On the mainland, $W$. auropunctata tends to cohabit with the native ant assemblages and does not become overly abundant (Klotz et al. 1995, Deyrup et al. 2000). In the insular habitats of the Florida Keys, however, Fleming (in Wetterer \& Porter 2003) found that W. auropunctata accounts for as much as 97.6 percent of all ants observed at baiting stations.

Wasmannia auropunctata was introduced to Gabon's coasts sometime before 1914 (Santschi 1914) and has been further 
transported within the country, via both inadvertent and intentional transport by humans (Wetterer \& Porter 2003). The Congo Basin contains the only documented sites outside of Florida where $W$. auropunctata is unquestionably non-native, yet well established, in a natural mainland habitat. Although some anecdotal observations have been published on the topic (Wetterer et al. 1999, Wetterer \& Porter 2003, Walsh et al. 2004), no previous study has examined the impact of $W$. auropunctata on the native fauna of these habitats in an analytical, quantitative fashion.

The objective of this study was to evaluate the impact of $W$. auropunctata on native ant species in Gabon; a necessary step toward assessing what priority the control of this species should be given for conservation in equatorial Africa. A second objective was to map the distribution of $W$. auropunctata in a relatively recently invaded region in Gabon to better understand the rate and mechanism of local dispersion.

\section{METHODS}

STUDY SITE.-The study was conducted at the Station d'Etude des Gorilles et Chimpanzés (SEGC) research area in Lopé National Park, Gabon $\left(0^{\circ} 10^{\prime}-0^{\circ} 16^{\prime} \mathrm{S}, 11^{\circ} 33^{\prime}-11^{\circ} 39^{\prime} \mathrm{E}\right)$. The forests in Lopé are part of the Congo Basin rain forest block and are vital to many large mammals, including forest elephants and buffalos, gorillas, chimpanzees, and the largest known mandrill populations in the world (Blom et al. 1992).

This location is not only ecologically important, but also provides an ideal situation to compare sites where $W$. auropunctata has existed for varying durations due to documentation of the origin and subsequent expansion of the infestation. The introduction of $W$. auropunctata in the Lopé area can be reliably pinpointed to around 1965, when the first logging camp was established in the area that is now the SEGC research site. European foresters in Gabon, in addition to locals that knew the forest well, recall the sudden appearance of these fire ants shortly after logging activities began (SECG records; Wetterer et al. 1999). Since there had been no human settlements from the Ogooué River to the watershed of this area for at least $50 \mathrm{yr}$ prior to 1965 (Pourtier 1989), these claims are difficult to contest; they represent the only feasible explanation for the sudden appearance of exotic ants in this formerly remote location. Constant research activity in the area since 1983 provides records that document the subsequent spread of infestation in the area. Due to its slow rate of colonization when unassisted, W. auropunctata is not yet established throughout the entire SEGC research area, permitting comparison between infested and noninfested sites.

The ecological composition in Lopé is heterogeneous. I therefore examined ant assemblages in three different types of forest to assess whether the effect of $W$. auropunctata on local ants differs with forest composition. ( $c f$. White \& Abernethy 1996)

(1) Marantaceae forest: Immature forest with a dense understory layer of herbaceous plants mostly belonging to the Marantaceae and Zingiberaceae families.

(2) Open forest: Mature or otherwise closed-canopy forest, lacking dense understory layer of herbaceous plants.

(3) Bosquet: Small forest patch surrounded by savannah, which acts in many ways as an islet for microfauna.

Within each forest type, I selected three sites according to age of infestation by W. auropunctata (Table 1). Age of infestation was divided into three categories: No presence of $W$. auropunctata, presence of approximately $5 \mathrm{yr}$, and presence dating more than $10 \mathrm{yr}$. Infestation categories were assigned to sites based on the field notes of doctoral researchers which document the presence of the fire ants later identified as W. auropunctata in the focal areas of this study in 1983, 1993, 1995, 1996, 2000, and 2003 (SEGC, pers. comm.). These categories represent broad limits, and should not be interpreted as attempts to assign exact moments of colonization to any specific location. "Presence of approximately $5 \mathrm{yr}$," for example, means that $W$. auropunctata was found in a given area in 2000, but not in 1996. "Presence dating more than $10 \mathrm{yr}$ " means that the area was noted to be infested in 1993 or earlier.

Samples were collected during the wet season from March to June 2003. Because the forests in the area are heterogeneous, a twolevel sampling design was used. Within each site of roughly 1 ha, eight $314 \mathrm{~m}^{2}$ subsites were selected. Each subsite consisted of a circle with a $10 \mathrm{~m}$ radius. The center points of these circles were selected

TABLE 1. Site descriptions.

\begin{tabular}{|c|c|c|c|c|}
\hline B0 & Centroplacus & $0^{\circ} 12.0^{\prime} \mathrm{S}, 11^{\circ} 35.5^{\prime} \mathrm{E}$ & Bosquet & Absent \\
\hline O0 & Saline Three & $0^{\circ} 12.7^{\prime} \mathrm{S}, 11^{\circ} 36.3^{\prime} \mathrm{E}$ & Open & Absent \\
\hline M0 & Cephus & $0^{\circ} 12.4^{\prime} \mathrm{S}, 11^{\circ} 34.0^{\prime} \mathrm{E}$ & Marantaceae & Absent \\
\hline B5 & Klainedoxa & $0^{\circ} 11.8^{\prime} \mathrm{S}, 11^{\circ} 36.1^{\prime} \mathrm{E}$ & Bosquet & $\sim 5 \mathrm{yr}$ \\
\hline $\mathrm{B} 10$ & Camp Bosquet & $0^{\circ} 12.0^{\prime} \mathrm{S}, 11^{\circ} 36.0^{\prime} \mathrm{E}$ & Bosquet & $>10 \mathrm{yr}$ \\
\hline $\mathrm{O} 10$ & Saline Zero & $0^{\circ} 12.3^{\prime} \mathrm{S}, 11^{\circ} 36.2^{\prime} \mathrm{E}$ & Open & $>10 \mathrm{yr}$ \\
\hline M10 & Foret de l'aeroporte & $0^{\circ} 11.4^{\prime} \mathrm{S}, 11^{\circ} 36.6^{\prime} \mathrm{E}$ & Marantaceae & $>10 \mathrm{yr}$ \\
\hline
\end{tabular}


nonrandomly to best represent the dominant forest composition of the site. Individual sampling units were then located within each subsite by randomly selecting from 100 possible combinations of azimuth and distance from the center point. This two-level design ensured sample sites of fairly equal size and habitat composition and allowed for analysis of spatial heterogeneity both within and between subsites.

INVENTORY TECHNIQUE.-The ant inventory technique included direct searches, soil samples, and sweep netting. Direct searches consisted of five $1 \mathrm{~m}^{2}$ plots in each subsite (a total of 40 plots per site) that were searched thoroughly for ants by two people simultaneously for a period of $5 \mathrm{~min}$. The soil samples consisted of one $0.5 \mathrm{~m}^{2}$ plot in each subsite (a total of eight plots per site) in which the soil was removed to a depth of $3 \mathrm{~cm}$, and collected along with its leaf litter. The samples were then sifted to remove any ants. One sweep-netting sample was also taken at each subsite, yielding eight sweep-net samples per site. A sample consisted of five short transects walked at a steady pace while completing ten full $180^{\circ}$ sweeps with the net. The heavy net was vigorously swung through the vegetation at various heights to dislodge and catch ants (Fisher 2004). All inventory techniques were repeated for each combination of infestation category and forest type for a total of nine sites, 72 subsites, and 360, 72, and 72 sampling units for direct search, soil samples, and sweep net transects, respectively. Each of the three methods was conducted on three different days in each site to balance possible climatic effects on ant activity. No collecting was done within $24 \mathrm{~h}$ after any rainfall.

To map the distribution of W. auropunctata (Fig. 1), I walked around the perimeter of the forests in the principal SEGC research area, stopping at regular intervals to search thoroughly for W. auropunctata. In areas where I found infestations along the border, I conducted sweeps toward the interior of the forest with one to five assistants at regularly spaced intervals to determine the interior limit of the infestation. I also followed all waterways in contact with infested areas in both directions until I could no longer find $W$. auropunctata. Points delineating infestation borders were recorded using GPS and mapped in ArcGIS. I then connected the data points to represent the most likely continuous extent and estimated the area of this infestation using a basic ArcGIS query. I extended the distribution map beyond the principal SEGC research area and to the town of Lopé by visiting points along the main rivers and borders of forested areas within $100 \mathrm{~m}$ of the main road leading to SEGC.

DATA ANALYSIS.-Only ant workers were counted, since presence of alates does not necessarily indicate colony establishment (Fisher 2002). Species presence, rather than individual occurrence, was recorded for each sample. Voucher specimens have been

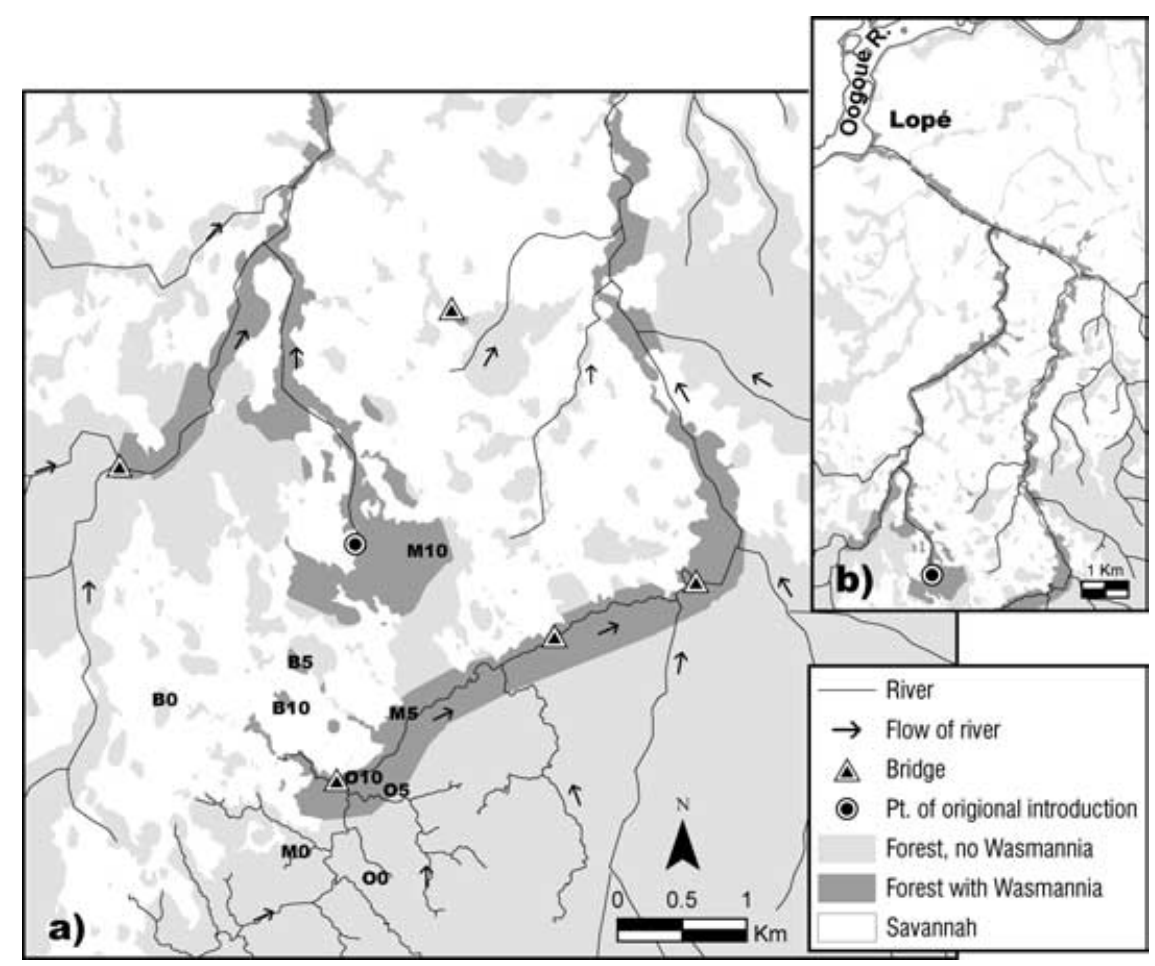

FIGURE 1. (a) Map of SEGC principal research area, showing study sites and extent of territory invaded by W. auropunctata in correlation with bridges and waterways. The assumed point of original infestation is determined by evidence from remains of the 1965 logging camp, as well as from SEGC records. (b) The infested area follows two small rivers through the northern border of the principal forest study area and continues several kilometers to the town of Lopé, where the smaller rivers meet up with the Oogoué, the largest river in Gabon. 
deposited at the California Academy of Sciences, San Francisco, California, U.S.A.

Statistical analyses were carried out using SPSS version 11. Nonparametric Kruskal-Wallis and Mann-Whitney $U$ tests were used to determine differences in species richness between sites. Since species richness alone is not always the best measure of diversity, evenness was also analyzed using a Simpson index: $\mathrm{D}=\sum \mathrm{n}_{i}\left(\mathrm{n}_{i}-\right.$ 1)/N(N-1), where $\mathrm{n}_{i}=$ the number of individuals of species $i$, and $N=$ the total number of individuals (Smith \& Wilson 1996).

To evaluate sampling efficiency, species accumulation curves were generated for each site in terms of new species found over total species encounters. The curves were generated based on the mean of 100 randomizations using Estimates 7.5 (Colwell 2005). The maximum likelihood asymptote of each curve was estimated using the Michaelis-Menten Means output (Raaijmakers 1987, Colwell \& Coddington 1994, Colwell 2005), which characterizes the main body of the community and provides a reliable estimate of sampling efficiency (Magurran 2004). Whereas the Michaelis-Menten asymptote may also provide an adequate estimate of total species richness (Soberón \& Llorente 1993), it tends to underestimate rare species (Magurran 2004). To estimate maximum species richness based on both common and rare species, the accumulation data were extrapolated using Incidence-based Coverage Estimator (ICE; Chao et al. 2000). Although such methods of estimating asymptotic richness via extrapolation of observed data show variable behavior and are still in a trial phase (Longino et al. 2002, Colwell et al. 2004), ICE has been shown to be a fairly robust species richness estimator across sites (Chazdon et al. 1998). ICE and Michaelis-Menten estimates are included here for their usefulness in visualizing and comparing the accumulation curves rather than to predict the exact species richness of each site. To accurately predict total species richness, more exhaustive sampling would be necessary (Longino $e t$ al. 2002).

Because the sample size for soil and sweep-net samples was small in comparison to that of direct search plots, the data collected from these former techniques were not included in statistical analysis, or in the generation of accumulation curves. For this reason, estimated species richness based on ICE and Michaelis-Menten only reflects ants found in direct search plots. Although excluded from statistical analysis, species observed in the soil and sweep-net samples are reported here as an indicator of species found in other strata of the forest. For an accurate assessment of diversity in these strata, more extensive sampling would be needed.

\section{RESULTS}

SPECIES RICHNESS. - With all sample methods, I collected a total of 79 ant species ( 20 genera) in all nine of the sites. A total of 75 , 17 , and 3 species were collected where W. auropunctata is not yet present, where it has been present for approximately $5 \mathrm{yr}$, and more than $10 \mathrm{yr}$, respectively. In the six invaded sites, W. auropunctata was found in every sample, using every sample method. In direct search plots, I found an average of $3.20,0.45$, and 0.14 other ant species per square meter for the above respective categories of $W$. auropunctata infestation.
A sharp decline in species richness accompanies infestation by W. auropunctata regardless of forest type (Fig. 2). Forest type did not significantly influence richness of ant species in the leaf litter (Kruskal-Wallis; $H=4.98 ; \mathrm{df}=2 ; P=0.083$ ). In contrast, the age of infestation by $W$. auropunctata had a highly significant impact on species richness (Kruskal-Wallis; $H=51.06$; $\mathrm{df}=2$; $P<0.001)$. Posthoc tests indicate that the most significant impact arises from the presence or absence of $W$. auropunctata regardless of the duration of infestation (Mann-Whitney; $U=0.0 ; P<0.001$ for both). The difference in ant species richness between sites where W. auropunctata has been present for $5 \mathrm{yr}$ and those where it has been present for more than $10 \mathrm{yr}$ was also significant $(U=194.5$; $P=0.038$ ), but the principal effect depended simply on presence.

The high significance of the results using only eight samples (eight five-plot clusters) per site rendered it unnecessary to extend the sample size to 40 by analyzing each plot as an independent sample. Since it is, therefore, unnecessary to evaluate the independence of the plots using spatial analysis of ant species between and within subsites, such spatial analysis is irrelevant to the scope of this paper.

SAMPLING EFFICIENCY AND PROJECTED SPECIES RICHNESS.-The species accumulation curves (Fig. 3) for all three sites not yet colonized by W. auropunctata were still rising at the end of the sampling period. The Michaelis-Menten asymptote estimation and the ICE estimation of minimum total species richness both considerably exceed the observed species for these sites (Table 2). In most of the sites infested by W. auropunctata, however, the accumulation curves flatten out with additional sampling effort, and the Michaelis-Menten asymptote estimation is equal to the number of species observed. The one exception is B5, for which the accumulation curve is still climbing with sampling effort.

EVENNESS.-The results generated by the Simpson index, which weights the abundance, or dominance, of each species in a site, are similar to those for pure species richness (Table 2). The sites that W. auropunctata has not yet colonized have considerably smaller Simpson values than those where W. auropunctata is present. These values reflect the probability of any two individuals drawn at random from the community belonging to the same species (Simpson 1949); values closer to zero represent more even assemblages with higher $\beta$ diversity.

DisTRIBUTION.—Wasmannia auropunctata infestations were found to cover approximately $6 \mathrm{~km}^{2}$ of forest habitat through the principal SEGC research area to the town of Lopé (Fig. 1). Colonization across dry land appears to be relatively slow. The widest patch of continuous infested territory away from waterways measured approximately $800 \mathrm{~m}$ across. If $W$. auropunctata colonized this area linearly from the point assumed to be the origin of introduction in 1965 (the site of the former logging camp), it would have advanced an average of about $21 \mathrm{~m}$ per year away from the river. If the precise origin of the infestation were not actually at this assumed point, this estimate of advancement rate would be reduced. In contrast, where moving water was present, the infestation extended much farther; W. auropunctata continued all the way down the rivers to 
(a) All habitats

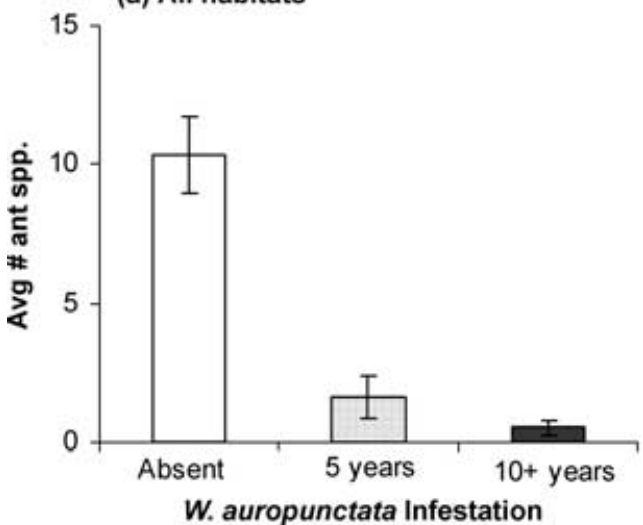

(b) Bosquet sub-sites

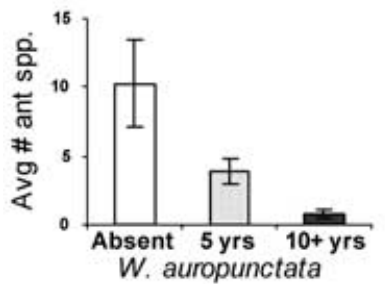

(c) Open forest sub-sites

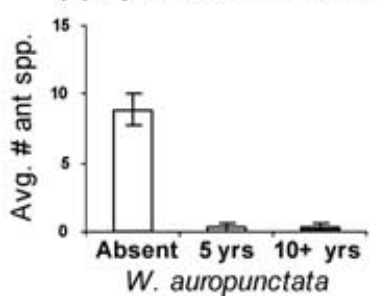

(d) Marantaceae sub-sites

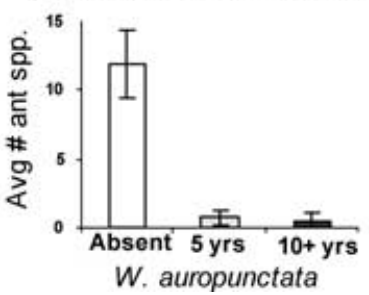

FIGURE 2. Average number of ant species found via direct search methods in subsites in (a) all habitats combined ( $N=24$ in each category), (b) bosquet subsites alone ( $N=8$ in each category), (c) open forest subsites alone ( $N=8$ in each category), and (d) marantaceae forest subsites alone $(N=8$ in each category). See text for description of habitats. Wasmannia auropunctata is not included in the calculations of ant species.

the town of Lopé, nearly $12 \mathrm{~km}$ away. Wasmannia auropunctata was frequently observed only within a narrow strip along the banks of these rivers, and was often absent in locations more than $20-30 \mathrm{~m}$ beyond these banks. Where infested areas crossed rivers, I found the upstream limit of $W$. auropunctata occurrence to lie almost exactly on the line connecting the two infestation boundary markers $20 \mathrm{~m}$ away from the river on each side. Downstream, however, infested areas projected past this line and always tend to follow the waterway.

The distribution of $W$. auropunctata in relation to bridges is striking. The vegetation in the direct vicinity of all the five bridges in the area was found to be infested. Infestations continued in the downstream direction from bridges, but hardly in the upstream direction unless there was another bridge upstream. One bridge stood within an isolated patch of W. auropunctata.

\section{DISCUSSION}

Wasmannia auropunctata reduces native ant diversity both radically and rapidly. Even with the limited sampling of this study, it is evident that native ant diversity is high in areas where this exotic ant is not present, and drops severely following infestations. The capability of $W$. auropunctata to eliminate almost all native ant species in the continental forests of Lopé presents a serious threat to the conservation of biodiversity in the Congo Basin region. The threat to ant diversity alone is substantial; nearby forests of the Monts Doudou area contain the highest ant richness known in
Africa (Fisher 2004). The threats extend beyond ants, however. Other studies have found that W. auropunctata can have indirect effects on lizard diversity (Jourdan et al. 2001), as well as direct effect on tortoises, birds (Lowe et al. 2000, Wetterer \& Porter 2003), and perhaps domestic dogs and cats (Wetterer et al. 1999) and their wild relatives (Walsh et al. 2004).

While W. auropunctata reportedly occupied an area of just over 60 ha at the SEGC study zone in Lopé in 2001 (Walsh et al. 2004), I found that the infestations covered more than 10 times that area in 2004. This enormous increase in infested territory is not likely due to an increase in colonization rate in the past $3 \mathrm{yr}$ : Differences in study area definition and survey methods are the more probable cause. Previous reports were based almost exclusively on researchers' records. Such records may provide reliable data for areas where researchers work often, but they tend to result in an underestimation of the total extent of the infestation because they provide little data for areas where research is rarely conducted.

Regardless of the rate at which these areas are being colonized, the extent of the infested territory in Lopé is alarming. Even more alarming is the relationship between infested areas and waterways. Whereas Walsh et al. (2004) call attention to the important role that logging activities play in the transport of $W$. auropunctata, they fail to recognize the significant role of rivers and streams in transporting the invaders. While rates of unassisted colonization away from rivers appear to be fairly slow, probably because Wasmannia alates do not fly very far (Lubin 1984), my results suggest that rates of 
(a) Bosquet plots

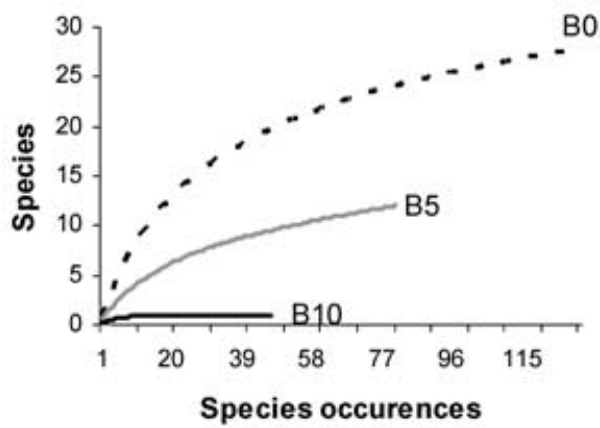

(c) Marantaceae forest plots

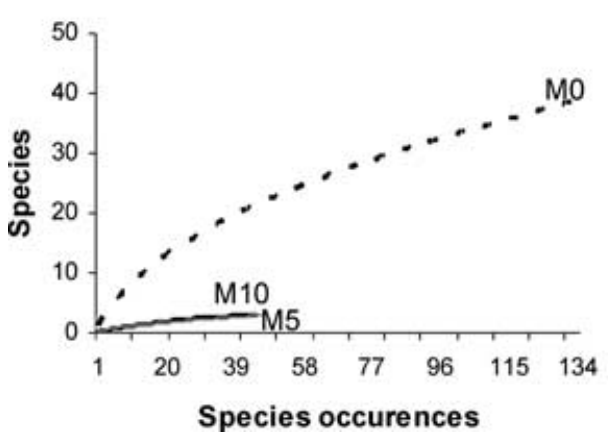

(b) Open plots
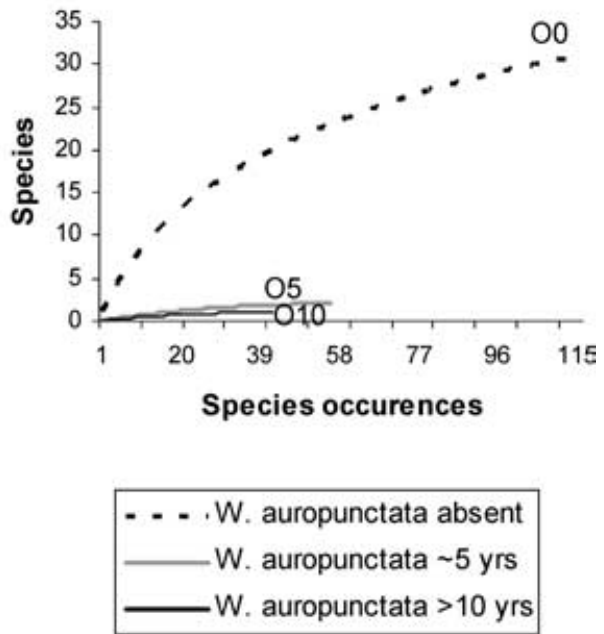

FIGURE 3. Assessment of effectiveness of direct search sampling $(N=40$ samples) in (a) bosquet sites, (b) open forest sites, and (c) marantaceae forest sites. The species accumulation curves in each graph plot the number of species observed as a function of species occurrences. Curves are plotted from the means of 100 randomizations of accumulation order. Asymptote and total species richness estimates based on these curves are summarized in Table 2 .

colonization are greatly accelerated when moving water is present. This relation to waterways is strikingly similar to patterns observed for other invasive ants, such as Linepithema humile (Holway 1998, Wild 2004).
The combination of logging and waterways can be an especially deadly mix for ant biodiversity. If $W$. auropunctata is introduced to a location near a waterway, it can expand its territory much more rapidly than on dry land, rendering early eradication nearly

TABLE 2. Diversity of ant assemblages found at each site, as determined by: the total number of ant species observed per site by all sampling methods and by direct search only, the mean number of ant species per subsite $(\mathrm{N}=8$ ), the mean number of ant species per plot $(\mathrm{N}=40)$, the Michaelis-Menten projected asymptote (MMM), the ICE estimate of total species richness, and the Simpson diversity index. Wasmannia auropunctata is not included in any figures.

\begin{tabular}{|c|c|c|c|c|c|c|c|c|c|}
\hline Site & Forest type & $\begin{array}{l}\text { Age of } \\
\text { infestation }\end{array}$ & \multicolumn{2}{|r|}{ Total spp. observed } & /subsite & $/ \mathrm{m}^{2}$ plot & MMM & ICE & Simpson \\
\hline B0 & Bosquet & absent & 35 & 27 & 10.25 & 3.53 & 33 & 33 & 0.06 \\
\hline $\mathrm{O} 0$ & Open & absent & 38 & 33 & 8.88 & 2.80 & 44 & 48 & 0.06 \\
\hline $\mathrm{O} 5$ & Open & $\approx 5 \mathrm{yr}$ & 2 & 1 & 0.25 & 0.05 & 4 & $2^{*}$ & 0.95 \\
\hline M5 & Marantaceae & $\approx 5 \mathrm{yr}$ & 5 & 3 & 0.75 & 0.23 & 4 & 7 & 0.70 \\
\hline $\mathrm{B} 10$ & Bosquet & $>10 \mathrm{yr}$ & 1 & 1 & 0.75 & 0.18 & 1 & $1^{*}$ & 0.75 \\
\hline $\mathrm{O} 10$ & Open & $>10 \mathrm{yr}$ & 1 & 1 & 0.25 & 0.05 & 2 & $1^{*}$ & 0.91 \\
\hline M10 & Marantaceae & $>10 \mathrm{yr}$ & 3 & 3 & 0.50 & 0.20 & 6 & 4 & 0.79 \\
\hline
\end{tabular}

*Stable for at least last five individuals added. 
impossible. The pattern of the distribution of W. auropunctata in relation to bridges in Lopé, along with the witness of locals and researchers in the area, strongly suggests that bridges are a primary means of secondary introduction. It is essential that special caution should be taken to prevent further spread of W. auropunctata when constructing bridges or transporting materials via such waterways.

Although bridges and waterways are particularly worrisome, transport of materials to remote areas for any reason and via any medium presents opportunity for invasions. If the control of $W$. auropunctata is not a priority, Gabon's national parks could easily facilitate, rather than prevent, the spread of this ant into pristine habitats, due to the extensive transport of materials required to develop and maintain these parks.

Conservationists and ecotourism operators should take all possible measures to avoid spreading W. auropunctata to noninfested areas. All materials transported into Gabon's national parks should be carefully inspected for W. auropunctata, and any new introduction should be immediately and completely eradicated before it becomes too extensive to control effectively. It is easy to overlook a tiny ant when facing more dramatic issues such as logging and poaching, but this tiny ant may be capable of taxing the forest's biodiversity to a similar extent.

\section{ACKNOWLEDGMENTS}

I thank CIRMF and the Wildlife Conservation Society for use of their research site and facilities, and K. Abernethy in particular for technical and moral support. I am grateful for the field assistance of C. Rembeyo, J. T. Dikangadissi, and E. Dimoto, who subjected themselves to the stings of Wasmannia to lend a hand. Special thanks to B. Fisher at the California Academy of Sciences, who provided facilities and guidance for ant identification. I am also grateful to B. Low, I. Perfecto, A. Kraljevic, B. Fisher, and J. Wetterer for providing insightful comments on my manuscript.

\section{LITERATURE CITED}

ATKINSON, I. 1989. Introduced animals and extinctions. In D. Western and M. C. Pearl (Eds.). Conservation for the twenty first century, pp. 5475. Oxford University Press, New York, New York.

Besselink, C., W. Ferwerda, And P. Sirs, Eds. 1998. The Congo Basin: Human and natural resources, pp. 214. Netherlands Committee for IUCN, Amsterdam, Netherlands.

Blom, A., M. P. T. Alers, A. T. C. Feistner, R. F. W. Barnes, and K. L. BARNES. 1992. Primates in Gabon-Current status and distribution. Oryx 24: 223-234.

Chao, A., W. H. Hwang, Y. C. Chen, and C. Y. Kuo. 2000. Estimating the number of shared species in two communities. Statistica sinica 10 : $227-246$.

Chazdon, R. L., R. K. ColWell, J. S. Denslow, and M. R. Guariguata. 1998. Statistical methods for estimating species richness of woody regeneration in primary and secondary rainforests of NE Costa Rica. In F. Dallmeier and J. A. Comiskey (Eds.). Forest biodiversity research, monitoring and modeling: Conceptual background of Old World case studies, pp. 285309. Parthenon Publishing, Paris, France.

Clark, D. B., C. Guayasamin, O. Pazmino, C. Donoso, and Y. P. DeVILLACIS. 1982. The tramp ant Wasmannia auropunctata: autecol- ogy and effects on ant diversity and distribution on Santa Cruz Island, Galapagos. Biotropica 14: 196-207.

ColWELL, R. K. 2005. EstimateS: Statistical estimation of species richness and shared species from samples. Version 7.5. User's Guide and application published at: http://purl.oclc.org/estimates.

—, AND J. A. CodDington. 1994. Estimating terrestrial biodiversity through extrapolation. Philos. Trans. R. Soc. (Series B) 345: 101-118. , C. X. MAO, AND J. CHANG. 2004. Interpolating, extrapolating, and comparing incidence-based species accumulation curves. Ecology 85: 2712-2727.

Deyrup, M., L. Davis, AND S. Cover. 2000. Exotic ants in Florida. Trans. Am. Entomol. Soc. 126: 293-326.

FISHER, B. L. 2002. Ant diversity patterns along an elevational gradient in the Reserve Speciale de Manongarivo, Madagascar. Boissiera 59: 311-328.

, Ed. 2004. Monts Doudou, Gabon: A floral and faunal inventory with reference to elevational variation, pp. 295. California Academy of Sciences, San Francisco, California.

Gillespie, R. G., AND G. K. RodericK. 2002. Arthropods on islands: Colonization, speciation, and conservation. Annu. Rev. Entomol. 47: 595632.

Guilbert, E., J. Chazeau, and L. Bonnet de Larbogne. 1994. Canopy arthropod diversity of New Caledonian forests sampled by fogging: Preliminary results. Mem. Queensl. Mus. 36: 77-85.

HoLWAY, D. A. 1998. Factors governing rate of invasion: A natural experiment using Argentine ants. Oecologia 115: 206-212.

Jourdan, H. 1997. Threats on Pacific islands: The spread of the tramp ant, Wasmannia auropunctata (Hymenoptera: Formicidae). Pac. Conserv. Biol. 3: 61-64.

— R. A. SACllier, AND A. M. Bauer. 2001. Little fire ant invasion (Wasmannia auropunctata) as a threat to New Caledonia lizards: Evidences from a sclerophyll forest (Hymenoptera: Formicidae). Sociobiology 38: 283-302.

Klotz, J. H., J. R. Mangold, K. M. Vail, L. R. Davis, and R. S. Patterson. 1995. A survey of the urban pest ants (Hymenoptera, Formicidae) of penninsular Florida. Fla. Entomol. 78: 109-118.

Le Breton, J., J. ChaZEAu, and H. Jourdan. 2003. Immediate impacts of invasion by Wasmannia auropunctata (Hymenoptera: Formicidae) on native litter ant fauna in a New Caledonian rainforest. Aust. Ecol. 28: 204-209.

—, H. Jourdan, J. Chazeau, J. Orivel, and A. Dejean. 2005. Niche opportunity and ant invasion: The case of Wasmannia auropunctata in a New Caledonian rain forest. J. Trop. Ecol. 21: 93-98.

Longino, J. T., J. A. Coddington, AND R. K. Colwell. 2002. The ant fauna of a tropical rain forest: Estimating species richness three different ways. Ecology 83: 689-702.

Loope, L. L., AND D. Mueller-Dombois. 1989. Characteristics of invaded islands. In $\mathrm{H}$. Mooney (Ed.). Ecology of biological invasions: A global synthesis, pp. 257-280. John Wiley \& Sons, Chichester, England.

LOWE, S., M. BROWNe, AND S. BOUdJELAS. 2000. 100 of the world's worst invasive alien species. Aliens 12: S1-S12.

LuBIN, Y. D. 1984. Changes in the native fauna of the Galapagos Islands following invasion by the little red fire ant, Wasmannia auropunctata. Biol. J. Linn. Soc. 21: 229-242.

MagurRan, A. E. 2004. Measuring biological diversity. Blackwell, Oxford, England.

Pourtier, R. 1989. Le Gabon: Etat et developpement. l'Harmattan, Paris, France.

RAAijMAKERS, J. G. W. 1987. Statistical analysis of the Michaelis-Menten equation. Biometrics 43: 793-803.

REJMÁNEK. 1996. Species richness and resistance to invasion. In G. H. Orians, R. Dirzo, and J. H. Cushman (Eds.). Biodiversity and ecosystem processes in tropical forests, pp. 153-172. Springer-Verlag, New York, New York.

SANTSCHI, F. 1914. Formicides de l'Afrique occidentale et australe du voyage de M. le Professeur F. Silvestri. Bollettino del Laboratorio di Zoologia general e agraria (Portici, Italia) 8: 309-385. 
Simpson, E. H. 1949. Measurement of diversity. Nature 163: 688.

SMITH, B., AND J. B. WILSON. 1996. A consumer's guide to evenness measures. Oikos 76: 70-82.

SOBERÓN, M., AND B. LLORENTE. 1993. The use of species accumulation functions for the prediction of species richness. Conserv. Biol. 7: 480.

Walsh, P. D., P. HensChel, AND K. A. Abernethy. 2004. Logging speeds little red fire ant invasion of Africa. Biotropica 36: 637-640.

Wetterer, J. K., And S. D. Porter. 2003. The little fire ant, Wasmannia auropunctata: distribution, impact, and control. Sociobiology 42: 141.
— P. D. WAlSh, AND L. J. T. White. 1999. Wasmannia auropunctata (Roger) (Hymenoptera: Formicidae), a destructive tramp-ant, in wildlife refuges of Gabon. Afr. Entomol. 7: 292-294.

WheELER, W. M. 1929. Two Neotropical ants established in the United States. Psyche 36: 89-90.

White, L. J. T., AND K. A. Abernethy. 1996. Vegetation Guide of the Lopé Reserve. ECOFAC, Libreville, Gabon.

WiLD, A. L. 2004. Taxonomy and distribution of the Argentine ant, Linepithema humile (Hymenoptera: Formicidae). Ann. Entomol. Soc. Am. 97: 12041215. 